\title{
Job CRAFTING AND ITS IMPACT ON WORK ENGAGEMENT AND Job SATiSfaCtion in Mining and ManUfacturing
}

\author{
Leon T de Beer \\ WorkWell Research Unit, North-West University \\ Maria Tims \\ Department of Management and Organization, Vrije University Amsterdam \\ Arnold B Bakker \\ Center of Excellence for Positive Organizational Psychology, Erasmus University Rotterdam \\ Accepted: March 2016
}

\begin{abstract}
The purpose of this study was to investigate job crafting and its relationship with work engagement and job satisfaction within the South African context. This research is important as job crafting has been shown to have a positive influence on employee motivation. A cross-sectional survey design was used to collect primary data from organisations in the mining and manufacturing industries of South Africa $(N=470)$. The results of multi-group structural equation modelling showed that the original four-factor structure of the job crafting scale was supported by the data, but that a three-factor structure was necessary due to a discriminant validity concern regarding two job crafting dimensions. Regression results revealed that increasing structural job resources with challenging job demands, and increasing social job resources were significant predictors of work engagement in both groups. Contrary to expectations decreasing hindering job demands was a negative predictor of job satisfaction in the mining group. Furthermore, increasing social job resources was also a significant predictor of job satisfaction in both groups. This study indicates the importance of job crafting for work engagement and job satisfaction in organisations.
\end{abstract}

Key words: job crafting, work engagement, job satisfaction, job design, proactive behaviour

JEL: M54

\section{$1 \quad$ Introduction}

In South Africa, mining contributes to about 18 per cent of gross domestic product (GDP) and to over 50 per cent of foreign exchange earnings (Smit, 2013). Similarly, manufacturing has been said to contribute to about 17 per cent of GDP (StatsSA, 2015) - indicating that both sectors are invaluable to the growth and success of the South African economy. However, in recent years these sectors have been impacted by frequent labour unrest (legal and wildcat strikes) and uncertainty surrounding employment (layoffs and retrenchments) and production are a great concern. For example, in platinum mining, a R 24 billion loss was estimated due to strike action (Steyn, 2014). Therefore, employees and organisations can benefit from employees who are proactive as organisations depend on their employees' proactivity in order to maintain competitive advantage due to constant changes in the market (Wagner \& Hollenbeck, 2015). This can be accomplished by having optimally motivated employees within a climate that takes the organisation forward. In the organisational behaviour literature employee motivation of this nature is most often referred to as work engagement - a positive, work-related frame of mind that is characterised by high levels of energy (vigour) and dedication in and to one's work (Schaufeli \& Bakker, 2004). Furthermore, in line with the job demands-resources model (JD-R; Bakker, Demerouti \& Sanz-Vergel, 2014), employees who receive the necessary job resources and have an optimal level of job demands (work characteristics) are not only motived and engaged, but are also overall more likely to be satisfied with their jobs. Job satisfaction can be defined as "a positive (or 
negative) evaluative judgment one makes about one's job or job situation" (Weiss, 2002:175). If employee work engagement and job satisfaction are not optimal, it can lead to various detrimental outcomes for the organisation, such as reduced commitment, lower productivity and increased employee turnover intention (Bakker \& Demerouti, 2007; De Beer, Rothmann Jr. \& Pienaar, 2012) - all of which are undesirable to an organisation as productivity and retention of talent are important aspects for business success which impacts the bottom-line.

Traditionally, from an organisational perspective, employees have been considered as passengers in their jobs and job (re)design was considered a reactive task - but an alternative has been posited that enables job (re)design at the individual level (see Tims \& Bakker, 2010). Employees who experience work engagement have been shown to create their own great places to work (Bakker, 2010). Organisations would therefore (and do) benefit from employees who take proactive initiatives in moulding their work characteristics (demands and resources) to best fit their needs and requirements (Parker, Williams \& Turner, 2006). In this sense, the organisation itself is not the sole proprietor of employee motivation and well-being, but employees themselves take action to increase their engagement and satisfaction with work by taking responsibility for altering job characteristics of their own volition (Tims, Bakker \& Derks, 2013). An employee therefore enters a job and proactively changes task-aspects of the job to better suit him or her (Bakker, Tims \& Derks, 2012). This proactive behaviour and personal initiative has been coined: Job crafting (Wrzesniewski \& Dutton, 2001). Job crafting is, in the context of the JD-R model, about moulding a job according to the employee's preferences, skills, and abilities - and thereby making actual changes in levels of job demands and job resources (Berg \& Dutton, 2008; Tims, Bakker \& Derks, 2012). It is important to note that job crafting and job (re)design are not interchangeable terms. Job redesign considers changes to the job as a whole and is a top-down approach, while job crafting is more concerned with task-related aspects of the job and is a bottom-up approach (Berg \& Dutton, 2008; Tims et al., 2012). Thus, in line with the JD-R model, job crafting addresses job demands and job resources (Tims \& Bakker, 2010), which can positively influence employee motivation, work engagement and job satisfaction.

Currently, no studies have been conducted on job crafting within the South African context. Due to its importance to organisations, a gap has been identified that needs to be addressed. Therefore, the present study aims to determine the factor structure of a recently proposed job crafting scale. In addition, we investigate the relationship of job crafting with work engagement and job satisfaction - two important indicators of employee motivation within mining and manufacturing organisations in South Africa.

\section{Literature review}

\subsection{Deconstructing job crafting}

Initially, it was hypothesised that job crafting comprises three components: i) increasing job resources, ii) increasing challenging job demands, and iii) decreasing hindering job demands (cf. Tims et al., 2012). Specifically, increasing one's level of job resources may have an impact on overall work engagement and motivation, as job resources have been shown to be the most important indicators of employee motivation - as presented in the motivational process of the JD-R model (Bakker \& Demerouti, 2007). Demerouti, Bakker, Nachreiner and Schaufeli (2001) describe job resources as the organisational aspects of the job that are instrumental in achieving work goals and may also reduce job demands. Some examples of job resources are social support, increased autonomy and participation in decision-making processes (Burke \& Richardsen, 1993). Conversely, Demerouti et al. (2001:501), and Schaufeli and Bakker (2004:296) define job demands as "those physical, psychological, social, or organisational aspects of the job that require sustained physical and psychological effort and are therefore associated with certain physiological and psychological costs". However, in terms of challenging job demands, research has shown that stimulating and challenging job tasks impact employee motivation positively (Crawford, LePine \& 
Rich, 2010; LePine, Podsakoff \& LePine, 2005), whereas hindering job demands have been shown to be related to employee exhaustion and cynicism (LePine et al., 2005; Van den Broeck, De Cuyper, De Witte \& Vansteenkiste, 2010). Hindering job demands contribute to the eroding of energy and health impairment that leads to burnout and eventually being unwell (Tadic, Bakker \& Oerlemans, 2015). Job crafters therefore address their job demands and job resources in a variety of constructive ways, like seeking resources (e.g., more autonomy on certain tasks, asking supervisors for more feedback regarding their performance), seeking challenges (e.g., challenging job demands to increase their mastery and personal growth), and reducing demands (e.g., hindering demands such as role conflict) (cf. Petrou et al., 2012).

The original development and validation study of the job crafting scale by Tims and colleagues revealed a four-factor structure for job crafting. Two of the original hypothesised factors were retained: i) increasing challenging demands and ii) decreasing hindering job demands; and two 'new' factors both represented the hypothesised concept of increasing job resources-behaviour and were labelled: iii) increasing structural job resources (e.g. autonomy, learning opportunities and variety) and iv) increasing social job resources (e.g. feedback, colleague support and supervisory coaching) (see Tims et al., 2012). The current study aimed to confirm this four-factor structure in a SouthAfrican sample of miners and manufacturers. Therefore the following hypothesis was stated:

$H_{1}$. The job crafting scale consists of a four-factor structure.

\subsection{Work engagement and job crafting}

Work engagement is classically defined as a "positive, work-related state of mind in employees characterised by vigour, dedication, and absorption" (Schaufeli, Salanova, Gonzalez-Roma \& Bakker, 2002:74). The core components of engagement comprise vigour and dedication (Bakker, Albrecht \& Leiter, 2011; Schaufeli \& Bakker, 2004), whereas absorption has been considered a more divergent component resulting from having the necessary vigour and dedication in one's work (see Langelaan, 2007). Vigour reflects high levels of energy and mental resilience at work (Bakker \& Demerouti, 2007; Schaufeli \& Bakker, 2010), whilst dedication reflects "a sense of significance, enthusiasm, inspiration, pride, and challenge" (Schaufeli \& Bakker, 2004:295).

Proactive behaviour and work engagement have shown a positive relationship, i.e. the act of being proactive has shown to increase work engagement (Bakker et al., 2012). Indeed, broadenand-build theory posits that positive affect broadens attention, cognition and action, which, in turn, leads to an increase in resources (Fredrickson, 2001; Fredrickson \& Branigan, 2005). Job crafting is an example of proactive behaviour and longitudinal research has found that job crafting is a mediator in the process of increasing work engagement and person-environment fit ( $\mathrm{Lu}$, Wang, Lu, Du \& Bakker, 2014). Job resources have also been shown to be the strongest predictors of work engagement (Bakker, Hakanen, Demerouti \& Xanthopoulou, 2007). Therefore, proactive actions by an individual that mobilises (and increases) job resources, decreases hindering job demands, and increases challenging aspects of a job, leads to work engagement (Bakker et al., 2012; Petrou et al., 2012; Tims et al., 2012; Tims et al., 2013). Based on the above the following hypothesis was stated:

$H_{2}$. Job crafting has a positive relationship to work engagement

\subsection{Job satisfaction and job crafting}

Job satisfaction is an affective state and indicates the overall level of satisfaction that an employee has towards his or her job situation (Weiss, 2002). It has also been argued that job satisfaction is a more passive state compared to work engagement, which is considered a more active one (Warr \& Inceoglu, 2012). This can be explained in the context of the circumplex model of emotion (Russell, 1980, 2003), which positions job satisfaction as characterised by low activation with positive (pleasant) affect - and work engagement having this positive affect but with high arousal (activation). Research has also shown that adequate job resources improve the job satisfaction levels of employees (Sousa-Poza \& Sousa-Poza, 2000). For example, increasing the quality of the exchange relationship with the supervisor (supervisor support - a social resource) has shown to 
increase job satisfaction and organisational citizenship behaviour (Li, Liang \& Crant, 2010). Therefore, the act of crafting can also increase the job satisfaction of employees (Tims et al., 2013). The following hypothesis is stated:

$H_{3}$. Job crafting has a positive relationship to job satisfaction.

The purpose of this study was to investigate the psychometric properties of the job crafting scale and its relationship with work engagement and job satisfaction within the South African context.

\section{Research methods}

This study consisted of a cross-sectional design (Struwig \& Stead, 2001). Cross-sectional research collects data at one point in time and considers the relationships between variables at that time (Struwig \& Stead, 2001; Welman, Kruger \& Mitchell, 2011). Therefore, primary data was collected from the organisations via survey implementation.

\subsection{Research participants}

The participants $(N=470)$ comprised of 260 employees in the mining sector $(55.7$ per cent of the sample), and 210 employees in the manufacturing sector ( 44.3 per cent of the sample). The mean age of the participants was 37.92 ( $\mathrm{SD}=11.4)$. Male participants numbered 263 (56 per cent) while females numbered 207 (44 per cent). The majority of the participants stated that they were married or living with a partner (63 per cent), whereas the minority indicated that they were remarried ( 3 per cent). The participants who were employed on a full-time basis numbered 451 (95.9 per cent), with 19 (4.1 per cent) employees indicated they were employed on a part-time basis. A total of 267 participants indicated their home language as being an African-language (56.8 per cent), whereas 199 participants' language was of Western-Germanic (English / Afrikaans) origin (42.3 per cent).

\subsection{Measuring instruments}

The measuring instruments used for the current study are described below. Please note that the reliability coefficients of the current study scales are provided in the results section below.

\subsubsection{Biographical questionnaire}

Standard biographical questions were used to determine the biographical characteristics of the participants, such as year of birth and gender.

\subsubsection{Job crafting}

Job crafting was measured with the Job Crafting Scale (JCS) developed by Tims et al. (2012). This scale uses a 5-point rating scale ranging from 1 (Never) to 5 (Often). The JCS posits four underlying factors measured by 21 items (e.g. 'I make sure that my work is mentally less intense' and 'When there is not much to do at work, I see it as a chance to start new projects'). This scale reported Cronbach's alpha coefficients of above 0.70 for all of the factors (Tims et al., 2012).

\subsubsection{Work engagement}

Work engagement was measured with items from the Utrecht Work Engagement Scale (UWES17; Schaufeli, Bakker \& Salanova, 2006). This measure classically consists of 17 items that are all scored on a 7-point rating scale ranging from 0 (Never) to 6 (Always). In this study only the 11 items measuring the two core components of work engagement were used: Vigour, (e.g. 'I can continue working for very long periods at a time') and Dedication (e.g. 'I find the work that I do full of meaning and purpose') (Schaufeli \& Bakker, 2004). The UWES has been used in South Africa with acceptable reliability ( $\alpha=0.78-0.89$; Storm \& Rothmann, 2003).

\subsubsection{Job satisfaction}

Job satisfaction was measured with the scale developed by Hellgren, Sjöberg and Sverke (1997). This three-item measure uses a 5-point scale ranging from 1 (Strongly disagree) to 5 (Strongly 
agree), to measure the individual's satisfaction with his or her job (e.g. 'I enjoy being at my job'). Within the South African context a Cronbach's alpha coefficient of 0.80 was found for this scale (Pienaar, Sieberhagen \& Mostert, 2007).

\subsection{Statistical analysis}

Multi-group confirmatory factor analysis (CFA; Brown, 2015) with structural equation modelling methods were implemented with Mplus 7.31 (Muthén \& Muthén, 2015). The weighted least square (WLS) estimation method, specifically the mean and variance adjusted weighted least squares (WLSMV) estimator was used. The justification for this implementation is based on the ordered categorical nature of the items (and not continuous nature as would be assumed by maximum likelihood estimation). A recent study has also shown that WLSMV can perform better with categorical data, compared even to Bayesian implementations, when sample size is 200 or above (Liang \& Yang, 2014). This approach was therefore considered appropriate to reach the objectives of the current study. The WLSMV estimation method provides the well-known global fit statistics for structural equation modelling methods: Comparative fit index (CFI; satisfactory values of 0.90 and above), Tucker-Lewis index (TLI; satisfactory values of 0.90 and above), and Root mean squared error of approximation (RMSEA; satisfactory value below 0.08) (Van de Schoot, Lugtig \& Hox, 2012).

Even though a polychoric correlation matrix is used between items in the estimation process of WLSMV, a zero-order correlation matrix is generated for the latent variables as latent variables are estimated to be continuous variable values from the ordered categorical indicators. In terms of the effect sizes for the correlation values, $r \geq 0.30$ was considered a medium practical effect, and $r$ $\geq 0.50$ was considered a large practical effect (Cohen, 1988). Problematic discriminant validity between latent variables would be investigated for high correlational values, i.e. $r \geq 0.85$ (Brown, 2015). Any potential concern of discriminant validity would be addressed by the average variance extracted (AVE) versus the shared variance between the constructs (Farrell, 2010). This technique assumes sufficient discriminant validity only if the AVE of each latent factor is larger than the shared variance between the two constructs being compared.

To determine the reliability of the constructs, alpha coefficients are normally calculated (Cronbach, 1951). However, Cronbach's alpha has been shown to be an inaccurate estimate of internal consistency and in some cases a gross overestimate (Revelle \& Zinbarg, 2009). Peters (2014) suggests abandoning Cronbach's alpha in psychological research altogether for other alternatives like the omega coefficient $(\omega)$ with bootstrapped 95 per cent confidence intervals (CIs). This study heeded that call and calculated omega reliability coefficients with 10000 bootstrap replications which provides 95 per cent confidence intervals for the reliability estimates (reported in the results section below).

Finally, a structural model was specified by adding regressions to the CFA (measurement) model in order to determine the standardised beta coefficients $(\beta)$ and standard errors (S.E.) for the direction of relationships between the latent variables. Statistical significance for all parameters in the study was set at the normal 95 per cent level $(p<0.05)$.

4 Results

Results of the structural equation modelling with Mplus, revealed the following:

\subsection{Measurement models (CFA), discriminant validity and reliability indicators}

The CFA results indicated that the four-factor measurement model for the components of job crafting showed a good fit to the data $(\mathrm{CFI}=0.95$; $\mathrm{TLI}=0.95$; $\mathrm{RMSEA}=0.05)$. However, upon closer inspection it was found that two of the four factors (Increasing structural job resources and Increasing challenging job demands) had a correlation of 0.86 in both the mining and manufacturing groups, which is above the set cut-off of 0.85 for discriminant validity (Brown, 2015). This then necessitated an investigation into the discriminant validity of these two constructs 
in the sample, i.e. whether these two factors could indeed be meaningfully distinguished from each other or if they needed to be combined as one factor in order to continue with the study investigations. The AVE and the shared variance between the two constructs in the two groups showed that in mining it was a borderline case while in the manufacturing group more shared variance was explained between the factors than in each individual latent variable. This indicated that there were indeed concerns with discriminant validity and it was decided to combine these two factors into a new factor labelled: Increasing structural job resources and challenging demands (Increasing S-JR and C-JD), to investigate the remaining two hypotheses. $\mathrm{H}_{1}$ was therefore partially supported.

The fit of the adjusted three-factor model to the data was also acceptable with deviations only occurring at the thousandth decimal $(\mathrm{CFI}=0.95$; TLI $=0.95$; RMSEA $=0.05)$. In this instance, no inordinate correlations were found in the correlation table, i.e. $r$ s $<0.85$ in all instances (see Table 2). The bootstrapped replicated omega reliability indicators showed that all three factors had acceptable reliability, i.e. internal consistency. More specifically, Increasing S-JR and C-JD (mining: $\omega=0.77,95 \% \mathrm{CI}[0.71,0.82]$; manufacturing: $\omega=0.83,95 \% \mathrm{CI}[0.79,0.86]$ ), Increasing social resources (mining: $\omega=0.73,95 \% \mathrm{CI}[0.68,0.77]$; manufacturing: $\omega=0.79,95 \% \mathrm{CI}[0.72$, $0.83]$ ), and Decreasing hindering job demands (mining: $\omega=0.76,95 \% \mathrm{CI}[0.70,0.80]$; manufacturing: $\omega=0.80,95 \% \mathrm{CI}[0.74,0.84]$ ) all had values above 0.70 in both groups (Dunn, Baguley \& Brunsden, 2014).

\subsection{Factor loadings and explained variance of the latent factors}

Table 1 presents the standardised factor loadings and variances explained of the individual items for each of the job crafting factors.

Table 1

Standardised factor loadings, standard errors and explained variance of the items for the job crafting factors

\begin{tabular}{|c|c|c|c|c|c|c|c|c|c|}
\hline Sector & Factor & Item & Loading & S.E. & $\mathbf{R}^{2}$ & Sector & Loading & S.E. & $\mathbf{R}^{2}$ \\
\hline \multirow{21}{*}{ Mining } & \multirow{10}{*}{ Increasing S-JR with C-JD } & 1 & 0.57 & 0.05 & 0.33 & \multirow{21}{*}{ Manufacturing } & 0.76 & 0.04 & 0.57 \\
\hline & & 2 & 0.71 & 0.04 & 0.50 & & 0.76 & 0.04 & 0.57 \\
\hline & & 3 & 0.85 & 0.04 & 0.72 & & 0.82 & 0.04 & 0.68 \\
\hline & & 4 & 0.81 & 0.04 & 0.65 & & 0.84 & 0.03 & 0.70 \\
\hline & & 5 & 0.27 & 0.04 & 0.07 & & 0.34 & 0.06 & 0.12 \\
\hline & & 17 & 0.62 & 0.04 & 0.58 & & 0.56 & 0.05 & 0.54 \\
\hline & & 18 & 0.53 & 0.04 & 0.38 & & 0.60 & 0.05 & 0.36 \\
\hline & & 19 & 0.55 & 0.04 & 0.47 & & 0.72 & 0.04 & 0.46 \\
\hline & & 20 & 0.43 & 0.05 & 0.31 & & 0.52 & 0.05 & 0.51 \\
\hline & & 21 & 0.59 & 0.04 & 0.25 & & 0.66 & 0.04 & 0.42 \\
\hline & \multirow{5}{*}{ Increasing social job resources } & 12 & 0.64 & 0.04 & 0.41 & & 0.68 & 0.05 & 0.48 \\
\hline & & 13 & 0.71 & 0.04 & 0.41 & & 0.77 & 0.04 & 0.47 \\
\hline & & 14 & 0.60 & 0.05 & 0.51 & & 0.68 & 0.05 & 0.58 \\
\hline & & 15 & 0.65 & 0.04 & 0.37 & & 0.76 & 0.05 & 0.47 \\
\hline & & 16 & 0.56 & 0.05 & 0.42 & & 0.56 & 0.05 & 0.60 \\
\hline & \multirow{6}{*}{ Decreasing hindering job demands } & 6 & 0.76 & 0.04 & 0.31 & & 0.73 & 0.03 & 0.31 \\
\hline & & 7 & 0.62 & 0.04 & 0.38 & & 0.60 & 0.04 & 0.31 \\
\hline & & 8 & 0.68 & 0.04 & 0.29 & & 0.68 & 0.03 & 0.35 \\
\hline & & 9 & 0.56 & 0.05 & 0.31 & & 0.71 & 0.03 & 0.52 \\
\hline & & 10 & 0.50 & 0.05 & 0.18 & & 0.65 & 0.04 & 0.27 \\
\hline & & 11 & 0.64 & 0.05 & 0.35 & & 0.69 & 0.04 & 0.44 \\
\hline
\end{tabular}

Notes: $S-J R=$ structural job resources; $C$-JD = challenging job demands; all loadings significant at the $p<0.001$ level; $R^{2}=$ variance explained by the latent factor in indicator 
Results of the three-factor model revealed that all the items of the individual job crafting factors had statistically significant factor loadings $(\lambda)$. For example, for increasing S-JR with C-JD the item with the highest factor loading was item 3 in the mining group ("I try to learn new things at work"; $\lambda=0.85$ ) and item 4 ("I make sure that I use my capacities to the fullest"; $\lambda=0.84$ ) in the manufacturing group. For the second factor, Increasing social job resources, the item with the highest factor loading in both groups was item 13 ("I ask whether my supervisor is satisfied with my work"; mining: $\lambda=0.71$; manufacturing: $\lambda=0.77)$. The final factor, Decreasing hindering job demands, also had the same item with the highest loadings in both groups, i.e. item 6 ("I make sure that my work is mentally less intense"; mining: $\lambda=0.76$; manufacturing: $\lambda=0.73$ ). All in all, the factor loadings had significant loadings to their corresponding factors, with acceptable variances explained by the latent variables in the corresponding observed indicators.

\subsection{Correlation matrix for the study variables}

Table 2 presents the zero-order correlation matrix for the three-factor model with work engagement and job satisfaction included.

Table 2

Correlation matrix for the latent variables in both groups

\begin{tabular}{|l|c|c|c|c|c|}
\multicolumn{1}{|c|}{ Variables } & $\mathbf{1}$ & $\mathbf{2}$ & $\mathbf{3}$ & $\mathbf{4}$ & $\mathbf{5}$ \\
\hline 1. Increasing S-JR with C-JD & - & $0.45^{*}$ & -0.07 & $0.46^{*}$ & $0.67^{* *}$ \\
\hline 2. Increasing social job resources & $0.73^{* *}$ & - & 0.16 & $0.32^{*}$ & $0.49^{*}$ \\
\hline 3. Decreasing hindering job demands & $0.56^{* *}$ & $0.47^{* *}$ & - & -0.15 & -0.05 \\
\hline 4. Job satisfaction & $0.51^{* *}$ & $0.57^{* *}$ & $0.36^{*}$ & - & $0.70^{* *}$ \\
\hline 5. Work engagement & $0.52^{* *}$ & $0.53^{* *}$ & 0.25 & $0.68^{* *}$ & - \\
\hline
\end{tabular}

Notes: Mining below-left of the diagonal and manufacturing above-right of the diagonal; " medium practical effect; ${ }^{* *}=$ large practical effect

In terms of the job crafting factors, it was interesting to note that in the mining group all of these factors correlated with each other with at least medium practical effect $(r \mathrm{~s}=0.47-0.73)$. Furthermore, work engagement was positively correlated with Increasing S-JR with C-JD $(r=0.52$; large effect), Increasing social job resources $(r=0.53$; large effect $)$ and Decreasing hindering JD $(r=0.25$; small effect). All three of the job crafting factors in the mining group also correlated positively to job satisfaction.

In the manufacturing group Decreasing hindering job demands did not correlate with practical effect with Increasing social job resources $(r=0.16, p=0.042)$ and didn't at all correlate significantly with Increasing S-JR and C-JD $(r=-0.07, p=0.281)$. Increasing S-JR with C-JD and Increasing social job resources correlated positively practically significantly with work engagement $(r=0.67 ; r=0.46)$ and job satisfaction $(r=0.49 ; r=0.32)$. However, decreasing hindering job demands did not statistically significantly correlate with work engagement and correlated negatively with job satisfaction $(r=-0.15)$.

\subsection{Structural model results}

Structural regression paths based on the hypotheses were added to the three-factor measurement model to establish the structural model. Table 3 presents the results of the structural model's implementation.

As can be seen from Table 3, in terms of work engagement in both groups: Increasing S-JR with C-JD had a significant positive relationship to work engagement (Mining: $\beta=0.33$, S.E. $=$ $0.11, p=0.002$; Manufacturing: $\beta=0.56$, S.E. $=0.05, p \leq 0.001)$. Similarly, increasing social job resources had a significant positive relationship to work engagement in the mining $(\beta=0.33$, S.E. $=0.11, p=0.002)$ and manufacturing group $(\beta=0.24$, S.E. $=0.06, p \leq 0.001)$. In terms of Decreasing hindering job demands, there was no significant relationship to work engagement in either the mining $(p=0.211)$ or the manufacturing groups $(p=0.402)$. Therefore, $\mathrm{H}_{2}$ was only partially supported. 
Table 3

Regression results for the structural model

\begin{tabular}{|c|c|c|c|c|}
\hline Sector & Structural regression path & $\beta$ & S.E. & p \\
\hline \multirow{6}{*}{ Mining } & Increasing S-JR with C-JD $\rightarrow$ Work engagement & 0.33 & 0.11 & 0.002 \\
\hline & Increasing social JR $\rightarrow$ Work engagement & 0.33 & 0.11 & 0.002 \\
\hline & Decreasing hindering JD $\rightarrow$ Work engagement & -0.09 & 0.07 & 0.211 \\
\hline & Increasing S-JR with C-JD $\rightarrow$ Job satisfaction & 0.17 & 0.12 & 0.151 \\
\hline & Increasing social JR $\rightarrow$ Job satisfaction & 0.41 & 0.11 & 0.001 \\
\hline & Decreasing hindering JD $\rightarrow$ Job satisfaction & 0.07 & 0.09 & 0.423 \\
\hline \multirow{6}{*}{ Manufacture } & Increasing S-JR with C-JD $\rightarrow$ Work engagement & 0.56 & 0.05 & 0.001 \\
\hline & Increasing social JR $\rightarrow$ Work engagement & 0.24 & 0.06 & 0.001 \\
\hline & Decreasing hindering JD $\rightarrow$ Work engagement & -0.05 & 0.06 & 0.402 \\
\hline & Increasing S-JR with C-JD $\rightarrow$ Job satisfaction & 0.37 & 0.07 & 0.001 \\
\hline & Increasing social JR $\rightarrow$ Job satisfaction & 0.17 & 0.07 & 0.018 \\
\hline & Decreasing hindering JD $\rightarrow$ Job satisfaction & -0.15 & 0.07 & 0.020 \\
\hline
\end{tabular}

Notes: $\beta=$ Beta coefficient; S.E. = Standard error; $p=$ Two-tailed statistical significance; $S$-JR = structural job resources; $C-J D=$ challenging job demands; $J D=$ job demands; $J R=$ job resources

In terms of job satisfaction in the mining group, Increasing S-JR with C-JD did not have a significant relationship to job satisfaction $(p=0.151)$, and the case was the same for Decreasing hindering job demands and job satisfaction $(p=0.423)$. However, Increasing social job resources did have a significant positive relationship to job satisfaction $(\beta=0.41$, S.E. $=0.11, p \leq 0.001)$. For the manufacturing group, Increasing S-JR and C-JD $(\beta=0.37$, S.E. $=0.07, p \leq 0.001)$, and Increasing social job resources $(\beta=0.17$, S.E. $=0.07, p \leq 0.001)$ both had significant positive relationships to job satisfaction. However, Decreasing hindering job demands had a significant negative relationship to job satisfaction $(\beta=-0.15$, S.E. $=0.07, p=0.020) . \mathrm{H}_{3}$ was therefore also partially supported.

\section{Discussion}

The aim of this study was to investigate job crafting and its impact on both work engagement and job satisfaction in mining and manufacturing within the South African context. Structural equation modelling methods were applied to investigate the hypotheses.

Hypothesis 1 was partially supported as the four-factor model could be confirmed in both groups, but due to a discriminant validity issue it was necessary to combine increasing structural job resources and challenging job demands in order to offset the potential of multicollinearity in the model, which would distort results. The newly formed three-factor model was also a good fit to the data, did not contain discriminant validity concerns, and consisted of the following factors: Increasing structural job resources with challenging job demands (Increasing S-JR with C-JD), increasing social job resources, and decreasing hindering job demands. Interestingly, Tims et al. (2012) originally hypothesised a three-factor model, but the final three-factor model operationalised in the current study did also not reflect their original three-factor expectation. As to why increasing structural job resources and challenging job demands combine as one-factor in this study, a potential explanation is that when employees increase their level of autonomy, their perceptions of responsibility and challenge increase as well. In addition, when actively seeking challenging and complex new projects, one may also increase opportunities for growth and development (i.e. a structural job resource).

Hypothesis 2 was also partially supported; it was found in both the mining and manufacturing groups that Increasing S-JR with C-JD and Increasing social job resources had significant relationships to work engagement. This is in line with research that has stated that challenging job demands can increase employee motivation and work engagement levels (Bakker \& Sanz-Vergel, 2013; Christian, Garza \& Slaughter, 2011). Furthermore, previous studies have also shown that 
social support (e.g. colleague support and supervisory coaching) leads to an increase in employee work engagement (Bakker \& Demerouti, 2008; Bakker, Schaufeli, Leiter \& Taris, 2008). However, in both groups Decreasing hindering job demands did not have a significant relationship to work engagement. Classically, the JD-R model presents no direct relationship to job demands (e.g., work overload) work engagement (Bakker \& Demerouti, 2007), and increased work engagement has only been associated with challenging demands at work (Langelaan et al., 2006; Schaufeli et al., 2001). Therefore, the finding that decreasing hindering job demands does not significantly affect work engagement, in these two groups, is not necessarily a counter-intuitive finding and is in line with other studies (see Tims, Bakker \& Derks, 2015; Tims, Bakker \& Derks, 2014). Additionally, reducing workload may have a protective effect on well-being but also lessen employee urgency to action (Petrou et al., 2012).

In terms of job crafting and job satisfaction, hypothesis 3 was also only partially supported. In the mining group there was only one significant relationship, and that was the relationship indicating that Increasing S-JR may positively relate to job satisfaction. Similarly, this relationship was also significant in the manufacturing group. This is in line with research that has found that social support such as colleague support and immediate supervisor support is related to job satisfaction (Baruch-Feldman, Brondolo, Ben-Dayan \& Schwartz, 2002; Ducharme \& Martin, 2000; Ellinger, Ellinger \& Keller, 2003). Tims et al. (2013) found that job satisfaction is fuelled by resources such as autonomy and financial rewards. Furthermore, increasing S-JR with C-JD also had a significant relationship to job satisfaction, which is in line with research that has shown that an increase in job resources and challenging demands may lead to increased job satisfaction (LePine et al., 2005; Sousa-Poza \& Sousa-Poza, 2000).

Conversely, decreasing hindering job demands had a significant but negative relationship to job satisfaction. This result was unexpected, but also interesting. Previous research has stated that Decreasing hindering job demands can be a potential negative aspect of job crafting - i.e. it may result in task avoidance and procrastination (Oldham \& Hackman, 2010; Wrzesniewski \& Dutton, 2001), and this may then lead to lower levels of job satisfaction. Furthermore, the current research did not measure how successful employees are at achieving their job crafting goals, and as such we can only speculate why this relationship was evident. Perhaps the mere act of having to decrease hindering job demands could also be at such a level (and perhaps so unsuccessful) that it affects employee job satisfaction levels negatively - perhaps due to the rigidity of the regulated environment they find themselves in. As previously shown, hindrance demands affect job satisfaction negatively (LePine et al., 2005), and unsuccessful attempts at addressing these demands might lead to job dissatisfaction because the proactive behaviour is ineffective. More specifically, the appraisal of demands as being threatening or hindering evokes a negative emotional response and passive style of coping that can lead to avoidance and withdrawal (LePine et al., 2005).

\subsection{Limitations and recommendations}

The key limitation of this study was its cross-sectional nature and therefore assumptions of causality are cautioned. Although longitudinal research has been conducted in other contexts it remains necessary to investigate job crafting and its related outcomes within a South African context, over time. Furthermore, the results of the factor structure of job crafting in the current sample were interesting: While the original four-factor model could be confirmed with acceptable fit, a three-factor model was necessitated due to a discriminant validity concern between Increasing structural job resources and Increasing challenging job demands which had to be combined into one factor for thus study. Researchers in future studies of job crafting in South Africa should therefore ascertain if they face a similar situation by first considering the original four-factor model - in line with established literature - and investigate whether they face a similar situation in terms of discriminant validity as was the case in this study in order to elucidate the state of affairs within the South African context. This may also have been due to the interpretation 
of the items (language used), and an item bias study could also be conducted in order to investigate the parameters, i.e. within and between person fit.

A further limitation worth mentioning is that the current study only considered organisations in the mining and manufacturing sectors of South Africa - which are very important to the GDP of the South African economy, but somewhat limits the external validity of the findings. Future researchers should therefore also consider samples from other sectors such as information technology, higher education, and health care to answer questions surrounding job crafting. Finally, this study only considered positive consequences of job crafting but recent research has shown that detrimental effects (such as negative spill over to colleagues) are also possible (Demerouti, Bakker, \& Halbesleben, 2015; Tims, Bakker \& Derks, 2015) - indicating further possibilities for future research.

\subsection{Conclusion}

In conclusion, this study provided psychometric evidence for the factor structure and reliability of the job crafting scale. Job crafting was positively related to work engagement and job satisfaction in the mining and manufacturing industries. Specifically, increasing job resources and challenging job demands were positively related to work engagement and job satisfaction, whereas decreasing hindering job demands was unrelated or negatively related to these employee outcomes. Our findings suggest that supporting and enabling employees to craft their jobs by increasing their challenging job demands and resources (but not decreasing hindering job demands) may have a positive impact on both work engagement and job satisfaction.

\section{References}

BAKKER, A.B. 2010. Engagement and job crafting: Engaged employees create their own great place to work. In S. Albrecht (ed.) Handbook of engagement: Perspectives, issues, research and practice (pp. 229244). Northampton, MA: Edwin Elgar.

BAKKER, A.B., ALBRECHT, S.L. \& LEITER, M.P. 2011. Key questions regarding work engagement. European Journal of Work and Organizational Psychology, 20(1):4-28.

BAKKER, A.B. \& DEMEROUTI, E. 2007. The job demands-resources model: State of the art. Journal of Managerial Psychology, 22:309-328.

BAKKER, A.B. \& DEMEROUTI, E. 2008. Towards a model of work engagement. Career Development International, 13(3):209-223.

BAKKER, A.B., DEMEROUTI, E., \& SANZ-VERGEL, A.I. 2014. Burnout and work engagement: The JD$\mathrm{R}$ approach. Annual Reviews in Organizational Psychology and Organizational Behavior, 1:389-411.

BAKKER, A.B., HAKANEN, J.J., DEMEROUTI, E. \& XANTHOPOULOU, D. 2007. Job resources boost work engagement, particularly when job demands are high. Journal of Educational Psychology, 99(2): 274-284.

BAKKER, A.B., SCHAUFELI, W.B., LEITER, M.P. \& TARIS, T.W. 2008. Work engagement: An emerging concept in occupational health psychology. Work \& Stress, 22(3):187-200.

BAKKER, A.B. \& SANZ-VERGEL, A.I. 2013. Weekly work engagement and flourishing: The role of hindrance and challenge job demands. Journal of Vocational Behavior, 83(3):397-409.

BAKKER, A.B., TIMS, M. \& DERKS, D. 2012. Proactive personality and job performance: The role of job crafting and work engagement. Human Relations, 65(10):1359-1378.

BARUCH-FELDMAN, C., BRONDOLO, E., BEN-DAYAN, D. \& SCHWARTZ, J. 2002. Sources of social support and burnout, job satisfaction, and productivity. Journal of Occupational Health Psychology, 7(1): 84-93.

BERG, J.M. \& DUTTON, J.E. 2008. Crafting a fulfilling job: Bringing passion into work. [accessed from website of Positive Organizational Scholarship December 2014].

BROWN, T.A. 2015. Confirmatory factor analysis for applied research (2nd ed.) New York, NY: Guilford Press. 
BURKE, R.J. \& RICHARDSEN, A.M. 1993. Psychological burnout in organizations. Handbook of organizational behaviour. New York, NY: Marcel Dekker.

CHRISTIAN, M.S., GARZA, A.S. \& SLAUGHTER, J.E. 2011. Work engagement: A quantitative review and test of its relations with task and contextual performance. Personnel Psychology, 64(1):89-136.

COHEN, J. 1988. Statistical power analysis for the behavioral sciences $\left(2^{\text {nd }}\right.$ edn.) Hillsdale, NJ: Lawrence Erlbaum.

CRAWFORD, E.R., LEPINE, J.A. \& RICH, B.L. 2010. Linking job demands and resources to employee engagement and burnout: a theoretical extension and meta-analytic test. Journal of Applied Psychology, 95(5):834-848.

CRONBACH, L.J. 1951. Coefficient alpha and the internal structure of tests. Psychometrika, 22(3): 297-334. DE BEER, L., ROTHMANN JR., S. \& PIENAAR, J. 2012. A confirmatory investigation of a job demandsresources model using a categorical estimator. Psychological Reports, 111:528-544.

DEMEROUTI, E., BAKKER, A.B. \& HALBESLEBEN, J.R. 2015. Productive and counterproductive job crafting: A daily diary study. Journal of Occupational Health Psychology, 20(4):457-469.

DEMEROUTI, E., BAKKER, A.B., NACHREINER, F. \& SCHAUFELI, W.B. 2001. The job demandsresources model of burnout. Journal of Applied Psychology, 86(3):499-512.

DUCHARME, L.J. \& MARTIN, J.K. 2000. Unrewarding work, coworker support, and job satisfaction a test of the buffering hypothesis. Work and Occupations, 27(2):223-243.

DUNN, T. J., BAGULEY, T. \& BRUNSDEN, V. 2014. From alpha to omega: A practical solution to the pervasive problem of internal consistency estimation. British Journal of Psychology, 105(3):399-412.

ELLINGER, A.D., ELLINGER, A.E. \& KELLER, S.B. 2003. Supervisory coaching behavior, employee satisfaction, and warehouse employee performance: A dyadic perspective in the distribution industry. Human Resource Development Quarterly, 14(4):435-458.

FARRELL, A.M. 2010. Insufficient discriminant validity: A comment on Bove, Pervan, Beatty, and Shiu (2009). Journal of Business Research, 63(3):324-327.

FREDRICKSON, B.L. 2001. The role of positive emotions in positive psychology: The broaden-and-build theory of positive emotions. American Psychologist, 56(3):218-226.

FREDRICKSON, B.L. \& BRANIGAN, C. 2005. Positive emotions broaden the scope of attention and thought-action repertoires. Cognition \& Emotion, 19(3):313-332.

HELLGREN, J., SJÖBERG, A., \& SVERKE, M. 1997. Intention to quit: Effects of job satisfaction and job perceptions. Published in F. Avallone, J. Arnold, \& K. de Witte (eds.) Feelings work in Europe (pp. 415423). Milano, Italy: Guerini.

LANGELAAN, S. 2007. Burnout and work engagement: Exploring individual and psychophysiological differences. Doctoral dissertation, Utrecht University, The Netherlands.

LANGELAAN, S., BAKKER, A.B., VAN DOORNEN, L.J. \& SCHAUFELI, W.B. 2006. Burnout and work engagement: Do individual differences make a difference? Personality and Individual Differences, 40(3): 521-532.

LEPINE, J.A., PODSAKOFF, N.P. \& LEPINE, M.A. 2005. A meta-analytic test of the challenge stressorhindrance stressor framework: An explanation for inconsistent relationships among stressors and performance. Academy of Management Journal, 48(5):764-775.

LI, N., LIANG, J. \& CRANT, J.M. 2010. The role of proactive personality in job satisfaction and organizational citizenship behavior: A relational perspective. Journal of Applied Psychology, 95(2):395-404. LIANG, X. \& YANG, Y. 2014. An evaluation of WLSMV and Bayesian methods for confirmatory factor analysis with categorical indicators. International Journal of Quantitative Research in Education, 2(1):17-38. LU, C.Q., WANG, H.J., LU, J.J., DU, D.Y. \& BAKKER, A.B. 2014. Does work engagement increase person-job fit? The role of job crafting and job insecurity. Journal of Vocational Behavior, 84(2):142-152. MUTHÉN, L.K. \& MUTHÉN, B.O. 2015. Mplus user's guide (7th ed.) Los Angeles, CA: Muthén \& Muthén. OLDHAM, G.R. \& HACKMAN, J.R. 2010. Not what it was and not what it will be: The future of job design research. Journal of Organizational Behavior, 31:463-479.

PARKER, S.K., WILLIAMS, H.M. \& TURNER, N. 2006. Modeling the antecedents of proactive behavior at work. Journal of Applied Psychology, 91(3):636-652. 
PETERS, G.J.Y. 2014. The alpha and the omega of scale reliability and validity. The European Health Psychologist, 16(2):54-69.

PETROU, P., DEMEROUTI, E., PEETERS, M.C., SCHAUFELI, W.B. \& HETLAND, J. 2012. Crafting a job on a daily basis: Contextual correlates and the link to work engagement. Journal of Organizational Behavior, 33(8):1120-1141.

PIENAAR, J., SIEBERHAGEN, C.F. \& MOSTERT, K. 2007. Investigating turnover intentions by role overload, job satisfaction and social support moderation. SA Journal of Industrial Psychology, 33(2):62-67.

REVELLE, W. \& ZINBARG, R.E. 2009. Coefficients alpha, beta, omega, and the glb: Comments on Sijtsma. Psychometrika, 74:145-154.

RUSSELL, J.A. 1980. A circumplex model of affect. Journal of Personality and Social Psychology, 39:1161-1178.

RUSSELL, J.A. 2003. Core affect and the psychological construction of emotion. Psychological Review, 110:145-172.

SCHAUFELI, W.B. \& BAKKER, A.B. 2004. Job demands, job resources and their relationship with burnout and engagement: A multi-sample study. Journal of Organizational Behaviour, 25:293-315.

SCHAUFELI, W.B. \& BAKKER, A.B. 2010. Defining and measuring work engagement: Bringing clarity to the concept. In A.B. Bakker \& M.P. Leiter (eds.) Work engagement: A handbook of essential theory and research (pp. 10-24). New York, NY: Psychology Press.

SCHAUFELI, W.B., BAKKER, A.B. \& SALANOVA, M. 2006. The measurement of work engagement with a short questionnaire a cross-national study. Educational and Psychological Measurement, 66(4):701-716.

SCHAUFELI, W.B., SALANOVA, M., GONZALEZ-ROMÁ, V. \& BAKKER, A.B. 2002. The measurement of engagement and burnout: A confirmative analytic approach. Journal of Happiness Studies, 3:71-92.

SCHAUfELI, W.B., TARIS, T., LE BLANC, P., PEETERS, M., BAKKER, A.B. \& DE JONGE, J. 2001. Maakt arbeid gezond? Op zoek naar de bevlogen werknemer [Work and health: the quest of the engaged worker]. De Psycholoog, 36:422-428

SMIT, C. 2013. The role of mining in the South African economy. KPMG. Available at: http://www.sablog. kpmg.co.za/2013/12/role-mining-south-african-economy/ [accessed August 2015].

SOUSA-POZA, A. \& SOUSA-POZA, A.A. 2000. Well-being at work: A cross-sectional study of the levels and determinants of job satisfaction. The Journal of Socio-Economics, 29:517-538.

STATSSA. 2015. Economic growth. Available at: www.statssa.gov.za/?page_id=735\&id=1 [accessed August 2015].

STEYN, L. 2014. Tsunami mining strike changes landscape. Mail \& Guardian. Available at: http://mg.co.za/article/2014-06-26-tsunami-mining-strike-changes-landscape [accessed Junie 2015]. STORM, K. \& ROTHMANN, S. 2003. A psychometric analysis of the Utrecht Work Engagement Scale in the South African police service. SA Journal of Industrial Psychology, 29(4):62-70.

STRUWIG, F.W. \& STEAD, G.B. 2001. Planning, designing and reporting research. Cape Town: Pearson Education South Africa.

TADIC, M., BAKKER, A.B. \& OERLEMANS, W.G. 2015. Challenge versus hindrance job demands and well-being: A diary study on the moderating role of job resources. Journal of Occupational and Organizational Psychology, 88(4):702-725.

TIMS, M. \& BAKKER, A.B. 2010. Job crafting: Towards a new model of individual job redesign. $S A$ Journal of Industrial Psychology, 36(2):1-9.

TIMS, M., BAKKER, A.B. \& DERKS, D. 2015. Examining job crafting from an interpersonal perspective: Is employee job crafting related to the well-being of colleagues? Applied Psychology, 64(4):727-753.

TIMS, M., BAKKER, A.B. \& DERKS, D. 2014. Daily job crafting and the self-efficacy-performance relationship. Journal of Managerial Psychology, 29(5):490-507.

TIMS, M., BAKKER, A.B. \& DERKS, D. 2013. The impact of job crafting on job demands, job resources, and well-being. Journal of Occupational Health Psychology, 18(2):230-240.

TIMS, M., BAKKER, A.B. \& DERKS, D. 2012. Development and validation of the job crafting scale. Journal of Vocational Behavior, 80(1):173-186. 
VAN DEN BROECK, A., DE CUYPER, N., DE WITTE, H. \& VANSTEENKISTE, M. 2010. Not all job demands are equal: Differentiating job hindrances and job challenges in the Job Demands-Resources model. European Journal of Work and Organizational Psychology, 19(6):735-759.

VAN DE SCHOOT, R., LUGTIG, P. \& HOX, J. 2012. A checklist for testing measurement invariance. European Journal of Developmental Psychology, 9(4):486-492.

WAGNER, J.A. \& HOLLENBECK, J.R. 2015. Organizational behavior: Securing competitive advantage (2nd ed.) Routledge: New York, NY.

WARR, P. \& INCEOGLU, I. 2012. Job engagement, job satisfaction, and contrasting associations with person-job fit. Journal of Occupational Health Psychology, 17(2):129-138.

WEISS, H.M. 2002. Deconstructing job satisfaction: Separating evaluations, beliefs and affective experiences. Human Resource Management Review, 12(2):173-194.

WELMAN, C., \& KRUGER, F. \& MITCHELL, B. 2011. Research methodology for the business and administrative sciences (3rd ed.) South Africa: Oxford University Press.

WRZESNIEWSKI, A. \& DUTTON, J.E. 2001. Crafting a job: Revisioning employees as active crafters of their work. Academy of Management Review, 26(2):179-201. 